\title{
Anti-aging Effects of P7C3 in UVA-irradiated Human Dermal Fibroblasts
}

\author{
Joong Hyun Shim \\ Faculty of Cosmetics and Beauty Biotechnology, Semyung University, Jecheon-si, Chungcheongbuk-do, Korea
}

\author{
Corresponding author: Joong Hyun Shim, \\ Faculty of Cosmetics and Beauty \\ Biotechnology, Semyung University, 65 \\ Semyung-ro, Jecheon-si, Chungcheongbuk-do \\ 27136, Korea \\ Tel.: +82436491615 \\ Fax: +82 436491730 \\ Email: jhshim@semyung.ac.kr
}

\section{Received October 19, 2016}

Revised January 11, 2017

Accepted January 16, 2017

Published March 30, 2017

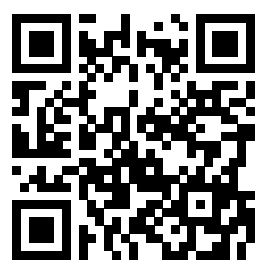

\begin{abstract}
Purpose: Ultraviolet (UV) radiation, specifically ultraviolet A (UVA), is known to induce photo-aging of human skin by promoting the aging phenomenon, such as skin elasticity reduction, wrinkle formation, and retardation of wound healing. Effects of P7C3, a small molecule neuroprotective drug candidate, were studied on the collagen, type I, alpha 1 (COL1A1) and matrix metallopeptidase 1 (MMP1) production in normal human face derived dermal fibroblasts (NHDFs), as a raw material of cosmetics. Methods: Cytotoxicity of the UVA on NHDFs was determined by cell counting kit-8 (CCK-8) assay. COL1A1 and MMP1 mRNA expressions were confirmed by two types of polymerase chain reaction (PCR), reverse transcription PCR and real-time PCR. In addition, wound healing assay was performed to demonstrate migration activity in P7C3-treated cells. Results: Increased COL1A1 production was observed by real-time PCR and COL1A1-enzyme linked immunosorbent assay (ELISA). The MMP1 expression was reduced by using UVA (5 $\mathrm{J} / \mathrm{cm}^{2}$ )-treated NHDFs. Furthermore, a scratch wound healing assay showed that P7C3 enhanced the migratory properties of UVA-irradiated NHDFs. Conclusion: The effects of P7C3 in improving aging skin were demonstrated in the cell efficacy test, and P7C3 is expected to have a value as an effective anti-aging material for functional cosmetics.
\end{abstract}

Keywords: P7C3, Ultraviolet, Collagen, Matrix metallopeptidase 1, Aging

\section{Introduction}

피부는 인체의 항상성을 저해하는 외부 인자의 위해를 막아주 는 최전방의 보호기관으로, 외부의 물리적, 화학적, 생물학적 장벽 기능을 수행하고 있을 뿐만 아니라 다양한 외부 요인과 접촉하고 있기 때문에 손상을 받기 쉽다(Lee et al., 2007; Yoon et al., 2013). 주요 스트레스 인자는 미생물의 번식, 미세먼지, 오염물질, 자외선 등을 대표적인 예로 들 수 있으며 이 요인들은 활성산소종(reactive oxygen species)을 생성하여 피부 세포의 손상 혹은 사멸을 유도하 고 피부노화를 유발한다(Kim et al., 2011; Yoon et al., 2013).

외부의 주요 스트레스 인자 중 자외선(UV)은 파장의 길이에 따 라 UVA (장파장, 320-400 nm), UVB (중파장, 290-320 nm), UVC (단파장, 200-290 nm)로 구분된다(Kim et al., 2011; Lee et al., 2007). 특별히 UVA는 피부 내 진피층까지 도달하여 섬유아세 포에 광노화를 유발하고 교원 및 탄력섬유의 변성으로 인한 피부
탄력 감소, 주름 형성, 광알러지, 피부암 등을 유발할 수 있다. 또 한, UVA 조사 후 진피층의 활성산소 증가와 섬유아세포의 1 형 콜 라겐(collagen, type I) 합성의 감소 및 기질금속단백분해효소 1 (MMP1)의 증가로 인한 광노화의 촉진이 보고된 바 있다(Cha \& Kim, 2015; Talwar et al., 1995; Yoon et al., 2013).

피부 진피층에 존재하는 섬유아세포는 중간엽 유래의 세포로서 연 결조직에 콜라겐 및 엘라스틴과 같은 세포외기질을 생성하는 역할을 담당한다. 섬유아세포의 기능을 간단하게 설명할 수는 있지만 각각 의 조직과 발생단계에서 존재하는 섬유아세포의 유래는 매우 상이하 다는 보고가 있다(Driskell \& Watt, 2015). 예를 들면 얼굴에 존재하 는 섬유아세포는 외배엽 유래의 신경절에서부터 발생되고, 복측 체 강에 존재하는 섬유아세포는 외측판 중배엽에서 발생되고, 후면 피 부에 존재하는 섬유아세포는 근육분절에서 유래한다(Fernandes et al., 2004; Jinno et al., 2010; Ohtola et al., 2008; Rendl et al., 2005; Wong et al., 2006). 미용측면에서 많은 연구자들이 가장 관심 
<smiles>OC(CNc1ccccc1)Cn1c2ccc(Br)cc2c2cc(Br)ccc21</smiles>

Empirical formula: $\mathrm{C}_{21} \mathrm{H}_{18} \mathrm{Br}_{2} \mathrm{~N}_{2} \mathrm{O}$

Molecular weight: 474.19

Figure 1. Structure of P7C3.

을 갖고 있는 부위는 얼굴로, 얼굴 진피층에는 외배엽 유래의 섬유아 세포로 발생과정을 거쳐 성체의 피부를 구성하게 된다.

피부의 탄력과 주름을 개선하고 진피층의 섬유아세포를 활성화 시키는 식품의약품안전처 고시 원료로는 레티놀(retinol), 아데노신 (adenosine) 등의 성분들이 있으며, 이들 성분을 함유한 제품들이 주름개선의 효과를 보이는 것으로 알려져 있다(Chan et al., 2006; Sorg et al., 2006). 이러한 성분은 기질금속단백분해효소의 활성을 억제시키거나 콜라겐의 생성을 촉진하여 피부노화를 개선한다고 알려져 있다. 그러나 고시원료 이외의 새로운 노화개선 소재의 개 발을 통해 기능성 화장품 시장의 선점과 확대가 필요한 시점이다.

신경계 질환의 신약후보물질의 평가를 위해 생쥐에서 해마의 흑 질 부위 손상을 유도해 파킨슨병 질병실험동물을 제작하여 치료 제 개발에 활용하고 있으며, 다양한 small molecules의 스크리닝 을 통해 P7C3라는 신경보호의 효과가 있는 aminopropyl carbazole 을 발견하였다(Hebert et al., 2004). P7C3는 파킨슨병 생쥐모델에 서 해마의 신경세포 신생에 도움을 주고 성숙한 뉴런을 보호하는 기능을 담당하며 비독성이면서 경구투여를 통해서도 생리적 기능 을 수행하고 대사적으로 매우 안전한 물질로 알려져 있다. 또한, 조 직에 존재하는 신경줄기세포의 증식을 유도하기 보다는 세포자멸 사(apoptosis)를 억제하여 세포사멸을 감소시켜 뉴런의 수를 증가 시키는 역할을 하여 종양발생의 위험이 적은 물질로 알려져 있고 (Naidoo et al., 2014; Pieper et al., 2010), 근위축성 축삭경화증을 지닌 실험동물에서 척수에 존재하는 운동뉴런을 보호하여 질병을
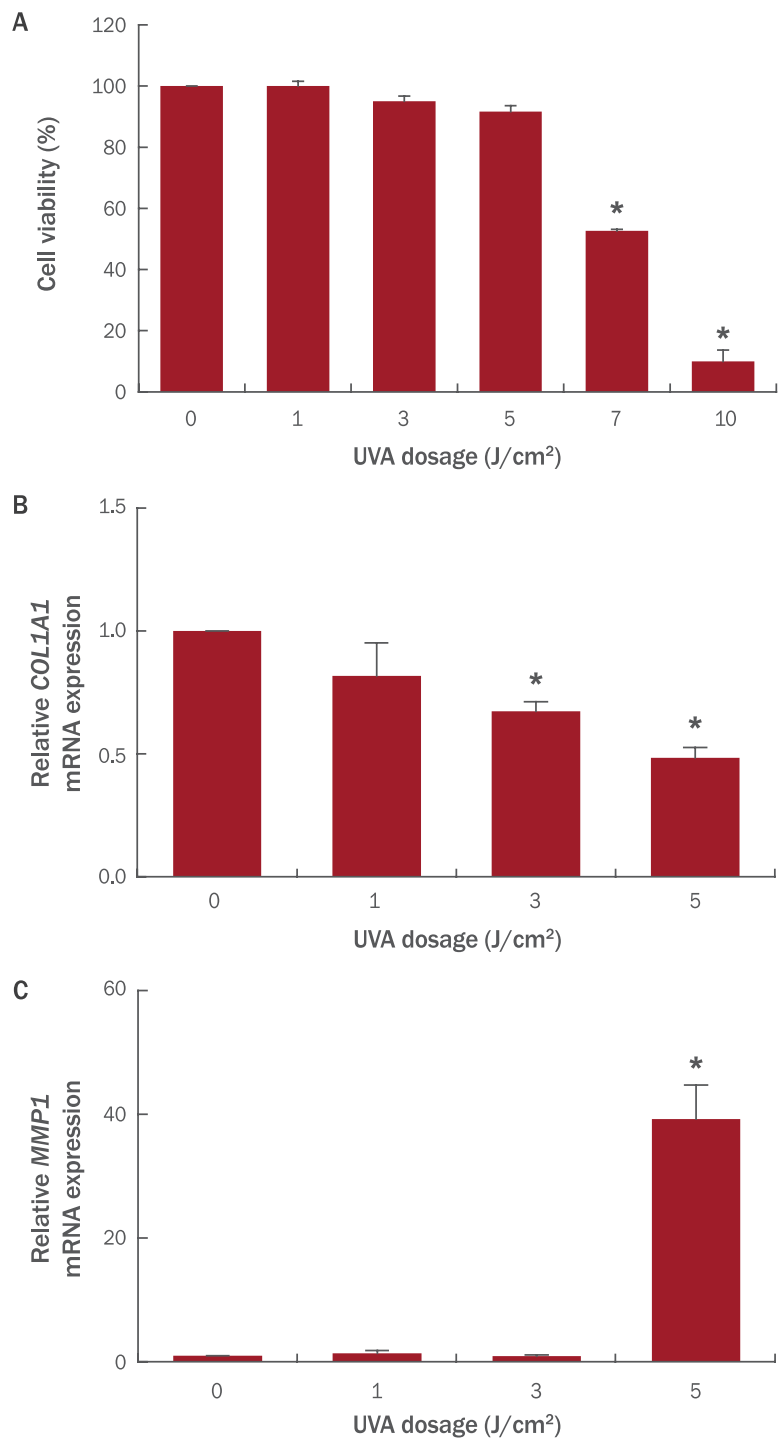

Figure 2. Cytotoxic effects of UVA irradiation on COL1A1 and MMP1 expressions in NHDFs.

(A) Ultraviolet A (UVA) irradiation was administered at various dosages and cell viability was measured by cell counting kit-8 assay. Real-time PCR was performed for collagen, type I, alpha 1 (COL1A1) (B) and matrix metallopeptidase 1 (MMP1) (C). The results are presented as mean \pm standard deviation $(\mathrm{M} \pm$ S.D.) of the percentage of control in triplicate. ${ }^{*} p<0.05$; NHDFs, normal human face derived dermal fibroblasts.

Table 1. Gene name and assay ID number in real-time PCR analysis

\begin{tabular}{lll}
\hline Symbol & Gene name & Assay ID \\
COL1A1 & Collagen, type I, alpha 1 & Hs00164004_m1 \\
COL3A1 & Collagen, type III, alpha 1 & Hs00943809_m1 \\
TIMP1 & TIMP metallopeptidase inhibitor 1 & Hs00171558_m1 \\
MMP1 & Matrix metallopeptidase 1 & Hs00899658_m1 \\
GAPDH & Glyceraldehyde-3-phosphate dehydrogenase & 43333764F \\
\hline
\end{tabular}

PCR, polymerase chain reaction. 
완화시킬 수 있다는 보고도 있다. 이외에 연령증가에 의한 뇌기능 의 감퇴와 외상성 뇌손상, 망막변성 등에 적용이 가능한 물질로 평 가되고 있다(Kemp et al., 2015) (Figure 1). 하지만 임상 3상에서 1,000 명의 알츠하이머 경중도 환자를 대상으로 한 최종 실험에 서 인지능력, 일상기능 등에서 증상개선을 확인하는데 실패하여 신약개발로의 진행이 중단된 상태이다. 하지만 학계에서는 P7C3 의 다양한 유도체를 합성하여 효능을 증가시켜 신경관련 질환 을 치료하려는 연구가 꾸준히 진행되고 있다(Kemp et al., 2015; Naidoo et al., 2014).

비독성이면서 안정한 물질로 평가되는 P7C3가 신경세포와 같은 외배엽 유래의 얼굴 섬유아세포에서 항노화 효능이 있는지에 대한 연구는 전무한 실정이다. 본 연구에서는 P7C3의 항노화 효과와 관 련하여 콜라겐과 $M M P 1$ 의 발현에 미치는 영향을 확인해 보고, 자 외선 조사에 의해 감소된 섬유아세포의 상처치유 능력이 P7C3에 의해 회복되는지 입증하고자 한다. 이를 통해 비독성이며 대사적으 로 안전한 $\mathrm{P} 7 \mathrm{C} 3$ 와 다양한 유도체의 향후 항노화 화장품 소재로서 의 가능성을 제시하고자 한다.

\section{Methods}

\section{1. 실험재료 및 세포배양}

실험재료는 98\% P7C3 (Sigma-Aldrich, USA)으로, P7C3는 물 에 용해되지 않기 때문에 dimethyl sulfoxide (Sigma-Aldrich)에 용해한 후 실험에 사용하였다. 본 실험에서는 $0.5 \mu \mathrm{M}$ 의 $\mathrm{P} 7 \mathrm{C} 3$ 를 처 리하여 실험을 진행하였다.

얼굴 유래 인간 피부 섬유아세포(NHDFs)는 Cell Applications (USA)에서 구매하여 사용하였으며, 세포배양을 위한 Dulbecco' s modified Eagle's medium (DMEM), fetal bovine serum (FBS) 는 Lonza (Switzerland)에서, 항생제(penicillin/streptomycin)은 Invitrogen $^{\mathrm{TM}}$ (Thermo Fisher Scientific, USA)에서 구입하여 사용 하였다. 섬유아세포는 8번째 계대배양 이내의 세포를 사용하였으 며, $37^{\circ} \mathrm{C}, 5 \% \mathrm{CO}_{2}, 100 \%$ 습윤배양기에서 배양하였다.

\section{2. 자외선 조사}

UVA 조사로 인한 섬유아세포의 노화를 확인하기 위해서 UVA를 하기와 같은 조건으로 처리하였다. 섬유아세포가 배양되고 있는 35 $\mathrm{mm}$ 조직배양접시에 phenol red가 첨가되지 않은 $\mathrm{DMEM}$ 을 $1 \mathrm{~mL}$ 접종한 후 자외선 조사장치(Bio-Link; Vilber Lourmat, France)를 사용하여 $5 \mathrm{~J} / \mathrm{cm}^{2}$ 의 UVA를 조사하였다.

\section{3. 세포 생존율 측정}

세포 생존율은 CCK-8 (Dojindo Molecular Technologies, Japan) 분석법을 이용하였다. $3 \times 10^{3}$ cells/well의 섬유아세포

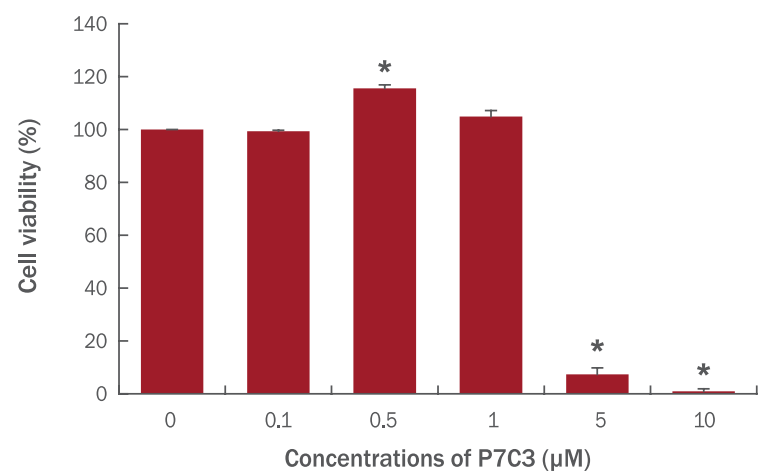

Figure 3. Cell viability of P7C3 in NHDFs.

NHDFs $\left(3 \times 10^{3}\right.$ cells/well) were seeded in 96-well plate and treated with indicated concentrations of P7C3 for $24 \mathrm{~h}$. Cell viability was measured by cell counting kit-8 assay. The results are presented as $\mathrm{M} \pm$ S.D. of the percentage of control optical density in triplicate. ${ }^{*} p<0.05$.

를 96-well 조직배양접시에 접종하고 $24 \mathrm{~h}$ 배양한 후 UVA $5 \mathrm{~J} /$ $\mathrm{cm}^{2}$ 를 조사한다. UVA가 조사된 섬유아세포를 $48 \mathrm{~h}$ 배양한 후 $\mathrm{CCK}-8$ 시약을 첨가하여 $2 \mathrm{~h}$ 동안 $37^{\circ} \mathrm{C}, 5 \% \mathrm{CO}_{2}$ 배양기에서 배 양하였다. ELISA reader (SPECTRAmax ${ }^{\circledR}$ PLUS $S^{384}$ Microplate Spectrophotometer; Molecular Devices, USA)를 사용하여 450 $\mathrm{nm}$ 에서 흡광도를 측정하였으며, 세포를 첨가하지 않은 배지만 넣 은 대조군의 흡광도를 기준으로 세포 생존율을 산출하였다. P7C3 의 처리농도를 결정하기 위한 평가법에서도 동일한 방법으로 세포 생존율을 산출하였다.

\section{RNA 추출 및 실시간 유전자 중합효소 연쇄반응(real-time PCR)}

TRIzol reagent (Thermo Fisher Scientific)를 사용하여 RNA 를 추출하였다. mRNA의 순도와 무결성은 A260/A280 nm 비 율 측정을 통해 확인하였으며, mRNA 수득율은 Epoch Microplate Spectrophotometer (BioTek Instruments, USA)를 사용하여 260 $\mathrm{nm}$ 에서 흡광도로 측정하였고, 사용 전까지 $-70^{\circ} \mathrm{C}$ 에서 보관하였 다. 추출한 RNA로부터 $\mathrm{cDNA}$ 의 합성은 SuperScript III Reverse Transcriptase (Invitrogen ${ }^{\mathrm{TM}}$, Thermo Fisher Scientific)를 사용 하여 합성하였으며, 섬유아세포 표지인자의 발현을 비교 측정하 기 위하여 real-time PCR (Applied Biosystems ${ }^{\mathrm{TM}}$, Thermo Fisher Scientific)을 진행하였다. TaqMan ${ }^{\circledR}$ Gene Expression Assays (Applied Biosystems ${ }^{\mathrm{TM}}$ )에 사용된 특정 유전자 정보는 Table 1과 같다. 결과는 glyceraldehyde-3-phosphate dehydrogenase (GAPDH)의 발현량에 대한 상대적인 발현량으로 계산하였다.

\section{Collagen, type I-ELISA}

$\mathrm{P} 7 \mathrm{C} 3$ 가 1형 콜라겐의 발현에 미치는 영향을 알아보기 위하여 $3 \times 10^{5}$ cells/well의 섬유아세포를 $60 \mathrm{~mm}$ 조직배양접시에 접종하 

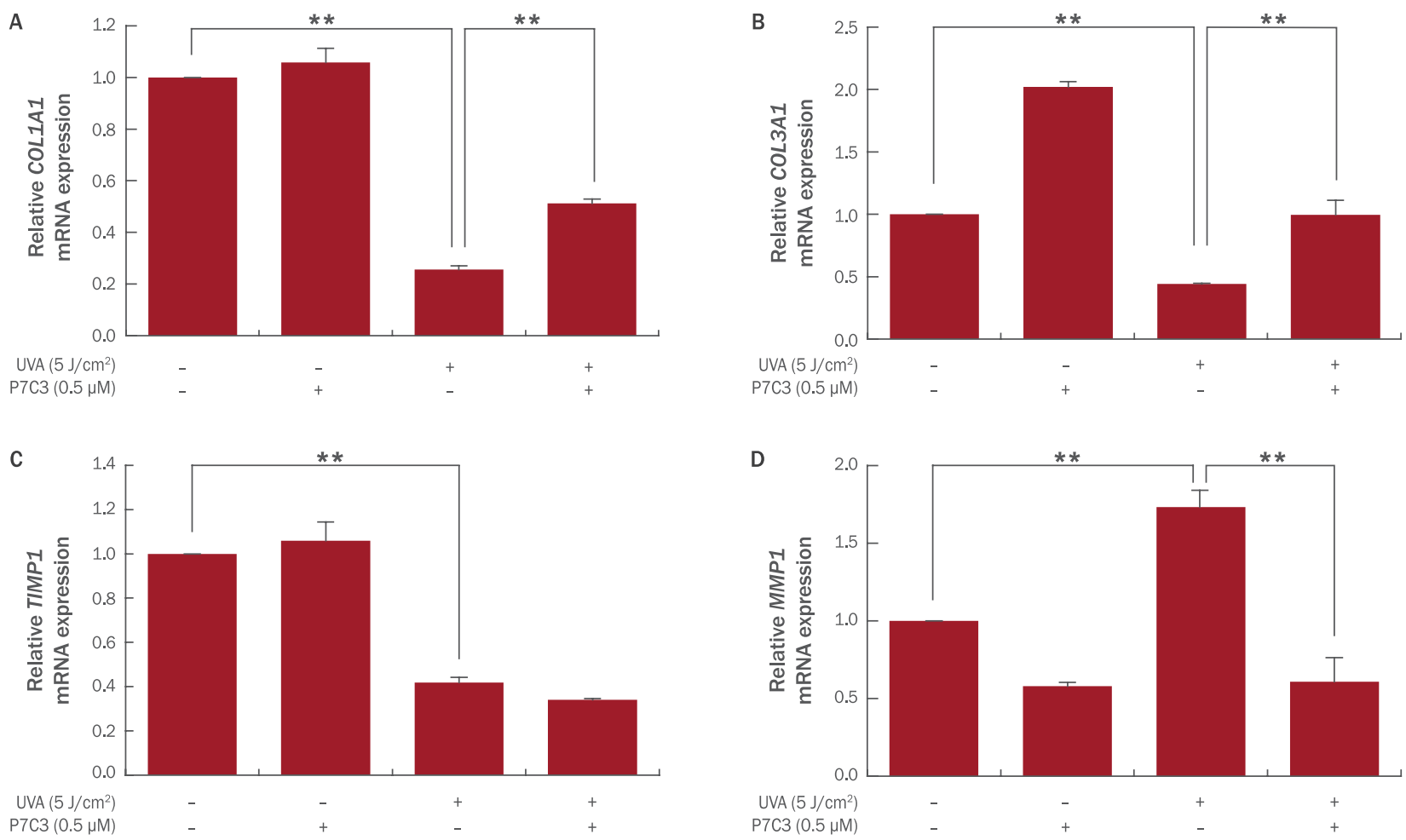

Figure 4. Characterization of P7C3 treatment on UVA-irradiated NHDFs.

Effects of P7C3 on the markers of NHDFs such as collagen, type I, alpha 1 (COL1A1) (A), collagen, type III, alpha 1 (COL3A1) (B), TIMP metallopeptidase inhibitor 1 (TIMP1) (C), and matrix metallopeptidase 1 (MMP1) (D) were confirmed by real-time PCR. Values represent $\mathrm{M} \pm$ S.D. of three independent experiments. ${ }^{* *} p<0.01$; UVA, ultraviolet A.

고 $24 \mathrm{~h}$ 동안 $37^{\circ} \mathrm{C}, 5 \% \mathrm{CO}_{2}$ 배양기에서 배양한 후, 자외선 조사기 를 통해 $5 \mathrm{~J} / \mathrm{cm}^{2}$ 의 UVA를 조사하였다. 조사 후 $0.5 \mu \mathrm{M} \mathrm{P} 7 \mathrm{C} 3$ 를 첨가하여 $48 \mathrm{~h}$ 동안 배양하였다. Procollagen Type I C-Peptide (PICP) EIA Kit (Takara Bio, Japan)를 이용하여 제조사의 방법을 따라 배양액의 1 형 콜라겐의 양을 측정하였다.

\section{Scratch wound healing assay}

섬유아세포를 6-well 배양접시에 $2 \times 10^{5}$ cells/well로 접종하고 80-90\%까지 배양한다. Phenol red가 첨가되지 않은 DMEM으로 배양배지를 교환하고 섬유아세포에 UVA $5 \mathrm{~J} / \mathrm{cm}^{2}$ 를 조사한 후, 1 $\mathrm{mL}$ 파이펫팁으로 배양접시를 긁어 상처를 발생시킨다. 배양접시 는 2차례 phosphate buffered saline으로 수세하고 무혈청 DMEM 에 $0.5 \mu \mathrm{M} \mathrm{P7C3를} \mathrm{첨가하여} 48 \mathrm{~h}$ 동안 배양한다. $\mathrm{P} 7 \mathrm{C} 3$ 의 상처치 유 효과를 확인하기 위하여 $0,24,48$ h마다 각 조건 별 동일 위치 에 현미경으로 사진촬영을 하였다.

\section{7. 통계분석}

통계처리는 일원배치 분산분석(one-way ANOVA)를 이용하였 으며 유의 수준을 $0.05(p<0.05)$ 로 하여 검정하였다.

\section{Results and Discussion}

\section{UVA 조사량에 따른 섬유아세포의 생존율과 섬유아세포의 표지인자 발현 분석}

노화의 진행은 조직과 기관의 항상성과 재생기능의 점진적인 감 소에 의한 현상이다(Kirkwood, 2005). 특별히 내인성 노화나 외인 성 노화(대표적으로 광노화)에 의한 피부의 노화는 피부의 탄력성 감소, 주름의 증가, 상처회복의 지연 등이 대표적인 특징이라 할 수 있다(Kim et al., 2011; Yaar \& Gilchrest, 2007).

산화스트레스를 유발하는 자외선 중에서 UVA는 UVB와는 다르 게 피부 진피의 깊은 층까지 투과할 수 있는 인자이다(Lee et al., 2007; Yaar et al., 2007; Yoon et al., 2013). 따라서 피부 진피층 에 도달하여 광노화를 유발하는 UVA를 섬유아세포 노화유발을 위 한 인자로 선정하였다. UVA가 섬유아세포에 미치는 독성을 알아 보기 위해, 섬유아세포에 각각 $1,3,5,7,10 \mathrm{~J} / \mathrm{cm}^{2}$ 로 UVA를 조사 하였다. 이후 $24 \mathrm{~h}$ 동안 배양한 후, CCK-8 assay로 섬유아세포의 생존율을 분석하였다. CCK-8 assay는 tetrazolium이 살아있는 세 포의 미토콘드리아 효소에 의한 formazan으로 변환되는 것을 측 정하는 분석법이다. $7 \mathrm{~J} / \mathrm{cm}^{2}$ 이상의 UVA가 조사된 섬유아세포에 


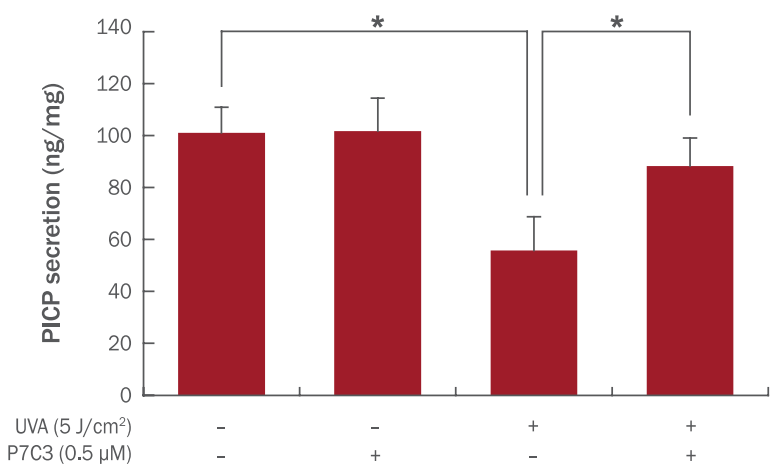

Figure 5. Effects of P7C3 on collagen synthesis in NHDFs. NHDFs were seeded in $60 \mathrm{~mm}$ culture dish and treated with P7C3 for $48 \mathrm{~h}$. Medium of the cell was collected and analyzed by procollagen type I C-peptide (PICP) EIA Kit. The data represent M \pm S.D. of three independent experiments. ${ }^{*} p<0.05$.

서 $50 \%$ 이상의 세포독성을 확인하였다(Figure 2A). 이후 1, 3, $5 \mathrm{~J} /$ $\mathrm{cm}^{2}$ 의 UVA를 조사한 실험군의 COL1A1과 $M M P 1$ 의 발현을 실시간 유전자 중합효소 연쇄반응으로 확인한 결과, COL1A1의 경우 3,5 $\mathrm{J} / \mathrm{cm}^{2}$ 의 자외선 조사에 의해 유의성 있게 발현이 감소하고(Figure $2 \mathrm{~B}), M M P 1$ 의 경우에는 $5 \mathrm{~J} / \mathrm{cm}^{2}$ 의 조사량에서 현저히 증가함을 확 인하였다(Figure 2C). 위의 결과를 바탕으로 섬유아세포의 노화조 건을 확립하기 위해 $5 \mathrm{~J} / \mathrm{cm}^{2}$ 의 UVA 조사량을 선정하였다.

\section{P7C3 농도별 섬유아세포의 생존율 분석}

섬유아세포에 대한 P7C3의 세포독성에 대한 영향을 확인하기 위하여 CCK-8 assay를 실시하였다. 대조군은 시료를 처리하지 않 았고, P7C3는 $0.1,0.5,1,5,10 \mu \mathrm{M}$ 의 농도로 처리하여 세포 생존 율을 측정하였다(Figure 3). $5 \mu \mathrm{M}$ 이상의 농도를 처리할 때 섬유아 세포의 생존율이 유의성 있게 감소하였고, $0.5 \mu \mathrm{M}$ 의 농도로 처리 시에는 섬유아세포의 생존율이 유의성 있게 증가함을 확인하여 본 실험에서는 $0.5 \mu \mathrm{M}$ 의 $\mathrm{P} 7 \mathrm{C} 3$ 를 처리하여 실험을 진행하였다.

\section{3. 자외선 조사와 P7C3 처리에 따른 섬유아세포의 mRNA 발현}

섬유아세포에 $5 \mathrm{~J} / \mathrm{cm}^{2}$ 의 $\mathrm{UVA}$ 를 한 차례 조사한 후 $0.5 \mu \mathrm{M}$ $\mathrm{P} 7 \mathrm{C} 3$ 를 처리하여 섬유아세포의 표지인자인 COL1A1, COL3A1, $T I M P 1, M M P 1$ 의 발현량을 실시간 유전자 중합효소 연쇄반응을 통 하여 확인하였다. 피부에서 콜라겐은 1형 콜라겐이 $80-85 \%, 3$ 형 콜라겐이 15-20\%를 차지하며 1형 콜라겐은 3 개의 아미노산 사슬 로 연결된 heterotrimer로 존재하고 있다(Dalgleish, 1997). 노화가 진행되면 1형 콜라겐의 $\mathrm{mRNA}$ 발현이 감소되고 피부와 근육의 탄 력성에 영향을 미친다(Furth, 1991; Martin et al., 1990; Stewart et al., 2006). 자외선 조사에 의해 섬유아세포는 무처리군 대비 COLIA1, COL3A1, TIMP1 등과 같은 특이적인 섬유아세포 표지인
자의 발현이 감소하고 $M M P 1$ 의 발현은 증가한다. $\mathrm{P} 7 \mathrm{C} 3$ 를 처리하 고 실시간 유전자 중합효소 연쇄반응을 통하여 섬유아세포의 표 지인자 발현을 확인한 결과, 자외선 처리군 대비 COL1A1의 발현 이 $100 \%, C O L 3 A 1$ 의 발현이 $125 \%$ 가량 증가하는 효과를 보였다 (Figure 4A, 4B). 반면 자외선 처리에 의해 감소되었던 TIMP 1 의 발현은 P7C3 처리에 의해 회복되는 효과는 보이지 않았다(Figure $4 \mathrm{C})$. 자외선 처리에 의해 증가되었던 $M M P 1$ 의 발현은 $\mathrm{P} 7 \mathrm{C} 3$ 에 의 해 $65 \%$ 감소하는 효과를 확인하였다(Figure 4D). 현재 여드름과 건선 등과 같은 다양한 피부과적 처치와 광노화의 개선 등에 사 용되는 all-trans retinoic acid는 콜라겐의 신생성과 $\mathrm{MMP} 1$ 의 발 현 억제에 작용하는 것으로 잘 알려져 있다(Griffiths et al., 1993; Shim et al., 2012). 본 실험을 통해 P7C3가 all-trans retinoic acid 와 유사한 결과를 보이는 것을 확인하였고 P7C3가 피부에 항노화 효능이 있는 것으로 사료된다.

\section{4. 자외선 조사와 P7C3 처리에 따른 1형 콜라겐 생성}

1 형 콜라겐 생성실험은 효소결합 면역흡착법(ELISA)을 사용하 여 측정하였다(Figure 5). 실험결과 무처리군 대비 자외선 조사에 의해 $45 \%$ 가량 생성이 감소되었던 1형 콜라겐이 $\mathrm{P} 7 \mathrm{C} 3$ 의 처리에 의 해 UVA 처리군 대비 $60 \%$ 가량 증가함을 확인하였다. 이러한 결과 를 바탕으로 $\mathrm{P} 7 \mathrm{C} 3$ 가 콜라겐 단백질 생성을 증가시키고 유전자 발 현에 영향을 미치는 것으로 사료된다.

\section{5. $\mathrm{P} 7 \mathrm{C} 3$ 의 상처치유 효과}

$\mathrm{P} 7 \mathrm{C} 3$ 가 자외선이 조사된 섬유아세포의 이동에 영향을 미치는 지 확인하기 위하여 상처치유 분석법을 실시하였다. 무처리군 대비 자외선이 조사된 섬유아세포는 대조군에 비해 현저하게 세포의 이 동이 감소되어 상처치유 능력이 떨어짐을 확인할 수 있었다. 반면 $\mathrm{P} 7 \mathrm{C} 3$ 처리군에서는 섬유아세포의 이동이 현저히 증가되어 자외선 에 의해 감소된 세포의 이동을 회복시킴을 확인하였다(Figure 6A). 섬유아세포의 이동에 의한 상처치유 회복을 수치화하기 위하여 1 $\mathrm{mL}$ 파이펫팁으로 긁어 상처가 유발된 초기 면적을 측정하고 각각 의 실험조건으로 $48 \mathrm{~h}$ 배양 후 최종 면적을 측정하여 퍼센트화 하 였다. 자외선이 조사된 섬유아세포는 대조군에 비해 세포가 이동한 면적이 $70 \%$ 가량 감소하였으나 $\mathrm{P} 7 \mathrm{C} 3$ 를 처리한 경우 $66 \%$ 증가함 을 확인하였다(Figure 6B). 이는 P7C3가 섬유아세포의 이동을 촉 진하고 상처치유를 유도하는 효과가 있음을 보여준다.

\section{Conclusion}

노화에 의해 피부는 두꺼워지고 주름이 형성되고 염증 등의 증 상이 나타나게 된다. 자외선과 같은 외부 환경뿐만 아니라 활성산 소종의 연쇄 반응을 통해 피부는 노화가 촉진되고 피부질환이 발생 
A

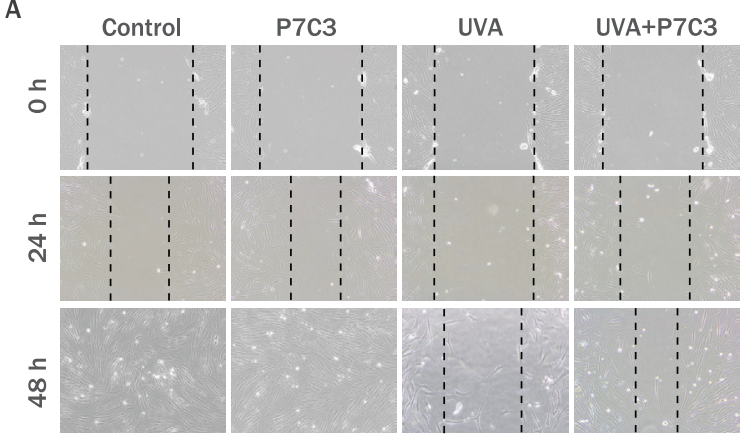

B

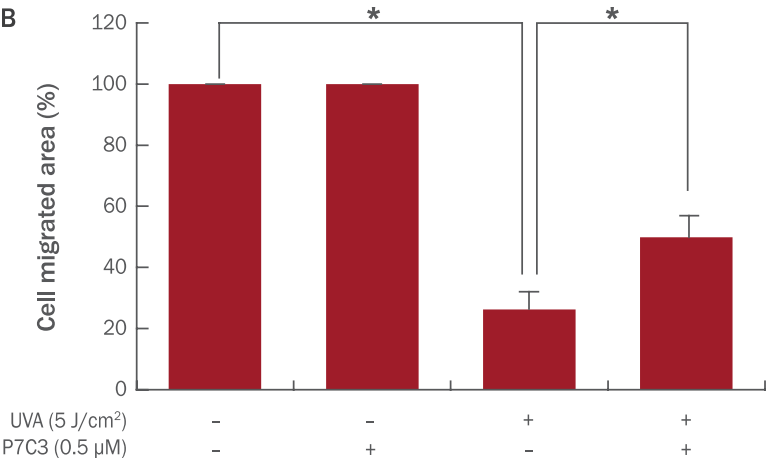

Figure 6. Increase in the migration of UVA-irradiated NHDFs by P7C3.

Scratch wound healing assays were performed using P7C3 in UVA-irradiated NHDFs for $48 \mathrm{~h}$. Images were obtained at 0, 24, and 48 h (magnification: $\times 100$ ) (A). Quantitative analysis of the scratch wound healing assay after $48 \mathrm{~h}(\mathrm{~B})$. The graphs are shown as $\mathrm{M} \pm \mathrm{S} . \mathrm{D}$. of three independent experiments. ${ }^{*} p<0.05$.

하게 된다(Kim et al., 2011; Talwar et al., 1995). 또한, 노화는 성 체 내 존재하는 구성세포의 감소 혹은 기능저하에 의해 정상적인 기능을 하는 조직으로의 재생 및 기능을 하지 못하게 된다(Jones \& Rando, 2011; Kirkwood, 2005).

본 연구에서는 섬유아세포에 처리할 $\mathrm{P} 7 \mathrm{C} 3$ 의 적절한 농도를 확인할 수 있었고, $0.5 \mu \mathrm{M}$ 의 농도에서는 세포의 생존율을 유의 성 있게 증가시킬 수 있음을 Figure 3에서 확인하였다. COL1A1, COL $3 A 1$ 의 유전자 발현 측정과 COL1A1의 단백질 발현 측정에서 $\mathrm{P} 7 \mathrm{C} 3$ 가 유의성 있게 자외선에 의해 감소된 발현을 회복시키는 결 과를 나타내었다(Figure $4 \mathrm{~A}, 4 \mathrm{~B}$, and 5). $M M P 1$ 의 발현 측정에서 는 P7C3가 자외선에 의해 증가된 발현을 감소시킬 수 있음을 보여 주었다(Figure 4D), 추가적으로 P7C3는 섬유아세포의 세포이동 을 유도하여 상처를 회복시키는 능력이 있음을 확인할 수 있었다 (Figure 6). 이는 P7C3가 새로운 피부 노화개선 후보물질로서의 가 능성을 보여준다. $\mathrm{P} 7 \mathrm{C} 3$ 는 최근 외배엽 유래의 신경세포의 세포자 멸사를 억제하며 신경세포의 증가를 유도시키는 반면 독성이 없고 종양의 생성을 유발하지 않는 뇌질환, 신경질환, 안질환 등에 적용 될 수 있는 신약후보물질로 개발되었다. P7C3의 피부노화 개선 효 과를 확인한 결과는 본 연구가 최초로, 추후 피부 미용에 실질적으 로 응용될 수 있고 피부노화를 예방할 수 있는 가능성을 제시한 결 과라 사료된다. 향후 $\mathrm{P} 7 \mathrm{C} 3$ 와 그 유도체가 어떠한 기전으로 자외선 에 의해 노화된 피부를 개선하는지에 대해 추가연구와 심도 있는 임상연구가 필요할 것으로 보인다.

\section{Acknowledgements}

이 논문은 2016 세명대학교 교내학술연구비 지원에 의해 수행된 연구임.

\section{References}

Cha $\mathrm{HJ}$, Kim YJ. Procyanidin B1 regualtes matrixmetalloprotease 1 mRNA expression using JNK-AP1-TRE axis in normal human dermal fibroblasts. Asian Journal of Beauty and Cosmetology, 13: 761-765, 2015.

Chan ES, Fernandez P, Merchant AA, Montesinos MC, Trzaska S, Desai A, Tung CF, Khoa DN, Pillinger MH, Reiss AB, et al. Adenosine A2A receptors in diffuse dermal fibrosis: pathogenic role in human dermal fibroblasts and in a murine model of scleroderma. Arthritis \& Rheumatology, 54: 2632-2642, 2006.

Dalgleish R. The human type I collagen mutation database. Nucleic Acids Research, 25: 181-187, 1997.

Driskell RR, Watt FM. Understanding fibroblast heterogeneity in the skin. Trends in Cell Biology, 25: 92-99, 2015.

Fernandes KJ, McKenzie IA, Mill P, Smith KM, Akhavan M, Barnabé-Heider F, Biernaskie J, Junek A, Kobayashi NR, Toma JG, et al. A dermal niche for multipotent adult skinderived precursor cells. Nature Cell Biology, 6: 10821093, 2004.

Furth JJ. The steady-state levels of type I collagen mRNA are reduced in senescent fibroblasts. The Journal of Gerontology, 46: B122-124, 1991.

Griffiths CE, Russman AN, Majmudar G, Singer RS, Hamilton TA, Voorhees JJ. Restoration of collagen formation in photodamaged human skin by tretinoin (retinoic acid). The New England Journal of Medicine, 329: 530-535, 1993. 
Hebert LE, Scherr PA, Bienias JL, Bennett DA, Evans DA. Statespecific projections through 2025 of Alzheimer disease prevalence. Neurology, 62: 1645, 2004.

Jinno H, Morozova O, Jones KL, Biernaskie JA, Paris M, Hosokawa R, Rudnicki MA, Chai Y, Rossi F, Marra MA, et al. Convergent genesis of an adult neural crest-like dermal stem cell from distinct developmental origins. Stem Cells, 28: 2027-2040, 2010.

Jones DL, Rando TA. Emerging models and paradigms for stem cell ageing. Nature Cell Biology, 13: 506-512, 2011.

Kemp SW, Szynkaruk M, Stanoulis KN, Wood MD, Liu EH, Willand MP, Morlock L, Naidoo J, Williams NS, Ready JM, et al. Pharmacologic rescue of motor and sensory function by the neuroprotective compound P7C3 following neonatal nerve injury. Neuroscience, 284: 202-216, 2015.

Kim J, Lee CW, Kim EK, Lee SJ, Park NH, Kim HS, Kim HK, Char K, Jang YP, Kim JW. Inhibition effect of Gynura procumbens extract on UV-B-induced matrix-metalloproteinase expression in human dermal fibroblasts. Journal of Ethnopharmacology, 137: 427-433, 2011.

Kirkwood TB. Understanding the odd science of aging. Cell, 120: 437-447, 2005.

Lee HY, Kim GJ, Kim YS, Lee SN, Lee SO. Skin science. Koonja Publishing, Seoul, pp20-24, 2007.

Martin M, el Nabout R, Lafuma C, Crechet F, Remy J. Fibronectin and collagen gene expression during in vitro ageing of pig skin fibroblasts. Experimental Cell Research, 191: 8-13, 1990.

Naidoo J, De Jesus-Cortes H, Huntington P, Estill S, Morlock LK, Starwalt R, Mangano TJ, Williams NS, Pieper AA, Ready JM. Discovery of a neuroprotective chemical, (S)$\mathrm{N}$-(3-(3,6-dibromo-9H-carbazol-9-yl)-2-fluoropropyl)-6methoxypyridin-2-amine [(-)-P7C3-S243], with improved druglike properties. Journal of Medicinal Chemistry, 57: 3746-3754, 2014.

Ohtola J, Myers J, Akhtar-Zaidi B, Zuzindlak D, Sandesara P, Yeh K, Mackem S, Atit R. beta-Catenin has sequential roles in the survival and specification of ventral dermis. Development, 135: 2321-2329, 2008.
Pieper AA, Xie S, Capota E, Estill SJ, Zhong J, Long JM, Becker GL, Huntington P, Goldman SE, Shen CH, et al. Discovery of a proneurogenic, neuroprotective chemical. Cell, 142: 39-51, 2010.

Rendl M, Lewis L, Fuchs E. Molecular dissection of mesenchymal-epithelial interactions in the hair follicle. PLoS Biology, 3: e331, 2005.

Shim JH, Shin DW, Lee TR, Kang HH, Jin SH, Noh M. The retinoic acid-induced up-regulation of insulin-like growth factor 1 and 2 is associated with prolidase-dependent collagen synthesis in UVA-irradiated human dermal equivalents. Journal of Dermatological Science, 66: 5159, 2012.

Sorg O, Antille C, Kaya G, Saurat JH. Retinoids in cosmeceuticals. Dermatologic Therapy, 19: 289-296, 2006.

Stewart TL, Jin H, McGuigan FE, Albagha OM, Garcia-Giralt N, Bassiti A, Grinberg D, Balcells S, Reid DM, Ralston $\mathrm{SH}$. Haplotypes defined by promoter and intron 1 polymorphisms of the COLIA1 gene regulate bone mineral density in women. The Journal of Clinical Endocrinology \& Metabolism, 91: 3575-3583, 2006.

Talwar HS, Griffiths CE, Fisher GJ, Hamilton TA, Voorhees JJ. Reduced type I and type III procollagens in photodamaged adult human skin. Journal of Investigative Dermatology, 105: 285-290, 1995.

Wong CE, Paratore C, Dours-Zimmermann MT, Rochat A, Pietri T, Suter U, Zimmermann DR, Dufour S, Thiery JP, Meijer $D$, et al. Neural crest-derived cells with stem cell features can be traced back to multiple lineages in the adult skin. The Journal of Cell Biology, 175: 1005-1015, 2006.

Yaar M, Gilchrest BA. Photoageing: mechanism, prevention and therapy. British Journal of Dermatology, 157: 874887, 2007.

Yoon Y, Bae S, An S, Choe YB, Ahn KJ, An IS. Effects of ultraviolet radiation on the skin and skin cell signaling pathways. Asian Journal of Beauty and Cosmetology, 11: 417-426, 2013. 


\section{국문초록}

\section{자외선 조사에 의해 노화된 인간 섬유아세포에서 P7C3의 항노화 효능}

심중현

세명대학교 화장품·뷰티생명공학부, 충청북도 제천시, 한국

목적: 자외선은 인간의 피부에 광노화를 유발하여, 피부 탄력 감소, 주름 형성 및 상처 치유 지연과 같은 피부노화현상을 야기한다고 알려져 있다. 신경보호제 후보물질로 알려진 P7C3의 화장품 원료로서의 가능성을 확인하기 위하여 얼굴 유래 인간 섬유아세포에서 P7C3에 의한 collagen, type I, alpha 1 (COL1A1)과 matrix metallopeptidase 1 (MMP1)의 발현양상과 상처치유 분석법을 수행하였다. 방법: Cell counting kit-8 (CCK-8) 분석법을 통해 세포독성평가와 이후 실험에 사용될 농도를 정하였다. Real-time polymerase chain reaction (real-time PCR)을 이용하여 COL1A1과 $M M P 1$ 의 mRNA 발현양상을 확인하였으며, $\mathrm{P} 7 \mathrm{C} 3$ 의 상처치유능을 wound healing assay를 통해 확인하였다. 결과: 자외선에 의해 발현이 감소된 COL1A1이 P7C3에 의해 증가되었고, 자외선에 의해 발현이 증 가한 $M M P 1$ 은 감소되었다. 더욱이 상처치유능 실험을 통해 $\mathrm{P} 7 \mathrm{C} 3$ 가 섬유아세포의 이동능력을 회복시켜 상처치유에 도움이 될 수 있 음을 확인하였다. 결론: 본 연구결과를 통하여 P7C3가 노화된 피부를 개선할 수 있음을 확인하였고, 향후P7C3가 기능성 화장품 개발 에 응용될 수 있는 소재로서의 가능성을 확인하기 위하여 추가적인 연구가 필요할 것이다.

핵심어: P7C3, 자외선, 콜라겐, Matrix metallopeptidase 1, 노화

이 논문은 2016 세명대학교 교내학술연구비 지원에 의해 수행된 연구임.

\section{참고문헌}

윤영민, 배승희, 안성관, 최용범, 안규중, 안인숙. 자외선(Ultraviolet)이 피부 및 피부세포 내 신호전달체계에 미치는 영향. 아시안뷰티화장품학술지, 11: 417-426, 2013.

이혜영, 김귀정, 김영순, 이성내, 이성옥. 피부과학. 군자출판사, 서울, pp20-24, 2007.

차화준, 김영주. 인간진피섬유아세포에서 코코아 주요성분인 Procyanidin B1이 JNK-AP1-TRE Axis를 통한 MatrixMetalloprotease 1 발현조절에 미치는 영향. 아시안뷰티화장품학술지, 13: 761-765, 2015. 


\section{中文摘要}

\section{P7C3对紫外线引起衰老的人真皮成纤维细胞的抗衰老功效}

沁重鉉

世明大學化妆品·美容生命工學科，忠淸北道堤川市，韩国

目的: 紫外线能够促使人体皮肤光老化，如皮肤弹性降低，波纹的形成以及伤口愈合迟缓等皮肤衰老现象都是由紫外线引 起的。为了探索具有神经保护作用的候选药物 P7C3作为化妆品原料的可行性, 在人真皮纤维细胞中 P7C3对 21 - 型胶原基因 （COL1A1），基质金属蛋白酶1的表达以及伤口愈合进行功效评价。方法: 利用 cell counting kit-8 (CCK-8)分析方法进行细 胞毒性评价并确定以后实验中采用的浓度。利用real-time polymerase chain reaction (real-time PCR)确认COL1A1和MMP1的 $m R N A$ 表达程度。利用伤口愈合实验确认P7C3的伤口愈合功效。结果: 通过利用P7C3，因紫外线照射而减少的COL1A1的表 达增加, 而因紫外线照射而增加的MMP1反而减少了。此外, 通过伤口愈合实验结果, P7C3能够恢复人真皮纤维细胞的移动 能力, 有助于伤口愈合。结论: 以上研究证明, P7C3能够改善衰老皮肤, 未来 P7C3作为功效性化妆品原料的适用可行性仍 需进一步的研究。

关键词: P7C3，紫外线，胶原蛋白，基质金属蛋白酶1，衰老 